\title{
Geography textbooks and the reproduction of a racist and ethnocentric world view among young people in Flanders
}

Handboeken aardrijkskunde en de reproductie van een racistisch en etnocentrisch wereldbeeld bij Vlaamse jongeren

\section{Nick Schuermans}

\section{OpenEdition}

\section{Journals}

Electronic version

URL: http://journals.openedition.org/belgeo/11594

DOI: $10.4000 /$ belgeo. 11594

ISSN: 2294-9135

\section{Publisher:}

National Committee of Geography of Belgium, Société Royale Belge de Géographie

Printed version

Date of publication: 31 December 2013

ISSN: 1377-2368

\section{Electronic reference}

Nick Schuermans, « Geography textbooks and the reproduction of a racist and ethnocentric world view among young people in Flanders », Belgeo [Online], 4 | 2013, Online since 24 June 2014, connection on 19 April 2019. URL : http://journals.openedition.org/belgeo/11594; DOI : 10.4000/ belgeo. 11594

This text was automatically generated on 19 April 2019.

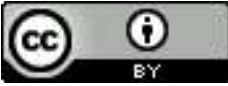

Belgeo est mis à disposition selon les termes de la licence Creative Commons Attribution 4.0 International. 


\title{
Geography textbooks and the reproduction of a racist and ethnocentric world view among young people in Flanders
}

\author{
Handboeken aardrijkskunde en de reproductie van een racistisch en \\ etnocentrisch wereldbeeld bij Vlaamse jongeren
}

Nick Schuermans

I would like to thank Maarten Loopmans, Henk Meert, Bruno Meeus, Etienne Van Hecke, Dirk Vanderhallen and two anonymous reviewers for their comments on earlier versions of this paper.

\section{Introduction}

1 In international comparisons, the Flemish youth often turns out to be rather racist and ethnocentric. Survey research demonstrates, for instance, that Flemish adolescents are on average more intolerant of foreigners than their peers in Canada or the Frenchspeaking south of Belgium. In Flanders, more than fifty per cent of the 16 and 17 year olds consider the presence of too many foreigners as a threat to their way of life. As much as 41 per cent of the Flemish youth has no trust at all in people of a different ethnicity (Claes et al., 2006).

2 This distrust of foreigners manifests itself in other studies as well. Focus group interviews on fear of crime in a technical school on the Flemish countryside revealed, for instance, that a lot of young adolescents are afraid of the city (Schuermans \& De Maesschalck, 2010). While some students are too scared to walk around in a town like Mechelen after dark, others do, but keep a constant eye on their belongings. Apparently, many students associate urban environments with unsafety and insecurity because of the presence of ethnic minorities. 
3 Such feelings of fear and distrust are generally not the result of long-standing relationships across ethnic and cultural groups. As much as two-thirds of the adolescents in Flanders do not have a single friend from another ethnic background (Claes et al., 2006). Most secondary schools in Flanders are strongly segregated along socio-economic and ethnic lines (Spruyt, 2008). Hence, opinions, attitudes and practices with regards to ethnic and cultural diversity are often shaped by talks with friends and family, media portrayals, statements by political parties and other outside influences, rather than by direct experiences, personal encounters and face-to-face contacts (cf. Valentine, 2008; Hemming, 2011).

Against this backdrop, this article questions to what extent Flemish geography textbooks disseminate or disturb a racist and/or ethnocentric world view among students. Drawing on the work of Edouard Vincke in Wallonia (1985 \& 1986) and Ineke Mok in the Netherlands (1995 \& 1999), I aim to answer the question whether these textbooks shatter a racist and ethnocentric world view or not. Even though students and teachers can engage with textbooks in many different ways, they provide a strong, authoritative voice about the state of the world. Together with newspaper articles, TV broadcasts, online websites and other textbooks, geography textbooks are an important source of information about other people in other places. In the words of Van Dijk (2005, p. 33), "many of the stereotypes and prejudices about others and the rest of the world are first learned and anchored in our youth, both through children's literature, TV programs and textbooks".

5 Flemish policymakers have clearly understood that children and adolescents build up part of their world view at school, and in geography lessons in particular, by learning about other countries, cultures and people. As a result, the final attainment levels of Flemish secondary geography education stress the importance of respect for other societies and the specific way of life of other people. Contemporary curricula focus more than ever on topics such as the global north-south divide, migrations and the multicultural city.

6 Based on an analysis of fifty Flemish geography published between 1896 and 2004, this paper critically addresses the way in which these topics have been presented until very recently. In doing so, this article builds upon previous studies on the reproduction of prejudices and biases in Flemish geography education. Kesteloot and Saey (1981) inferred, for instance, that geography lessons reproduce the unequal relationships between the different socio-economic classes. In their words, "school geography supports a world view in which this huge dichotomy, the adverse interests and the conflicts between the social classes are silenced" (p. 446). From a feminist perspective, Peleman (1998) added that geography textbooks have been quiet about gender inequalities for too long. While these scholars were mainly interested in the reproduction of class divisions and gender stereotypes in geography schoolbooks, this article will focus on the representation of racial classifications and cultural diversity in fifty textbooks in Flanders.

Obviously, such a small sample does not contain all textbooks published over all those years. By selecting different textbooks by different publishers, I try to bring the diversity of the textbooks in my sample. By selecting quotes from these textbooks, I aim to reveal themes that recur in most textbooks. As such, the quotes are meant to represent the hegemonic discourse that comes back in most or nearly all textbooks. In the next section, I will sketch this discourse in the colonial era (1908-1960). In sections 3 and 4, I do the same for the post-colonial era (1960-2004). Based on four critiques of the more recent 
textbooks, I will conclude with four propositions to write textbooks which motivate students to become part of a more inclusive, more diverse and more just society.

\section{The racial classifications of the colonial era}

In the first half of the twentieth century, the division of humanity in different races was a self-evident component of all Flemish geography textbooks. At that time, the typical classification rested on differences in skin colour, hair colour, eye colour, height and skull shape. Most authors defined three main races which were further subdivided into subraces. It was popular, for example, to classify white Europeans in three main varieties: the Nordic variety, the Mediterranean variety and the Alpine variety (Halkin, 1937, p. 49). In Belgium, most handbooks also made a distinction between the "blonde families" in the Flemish-speaking north and the "brown families" in the French-speaking south (Roland, 1896, p. 42; Halkin, 1927, p. 24). Nonetheless, the classification of humanity in three different races always got the most attention. Drawings (figure 1) and maps (figure 2) illustrated the lengthy descriptions of the white, yellow and black races:

Figure 1. The classification of humanity in three races.

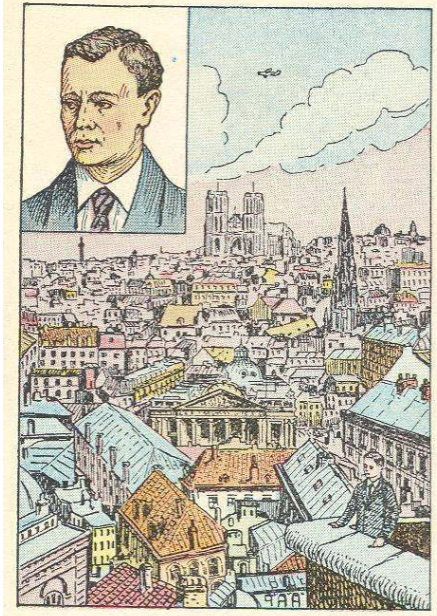

1. - Blanke ras.

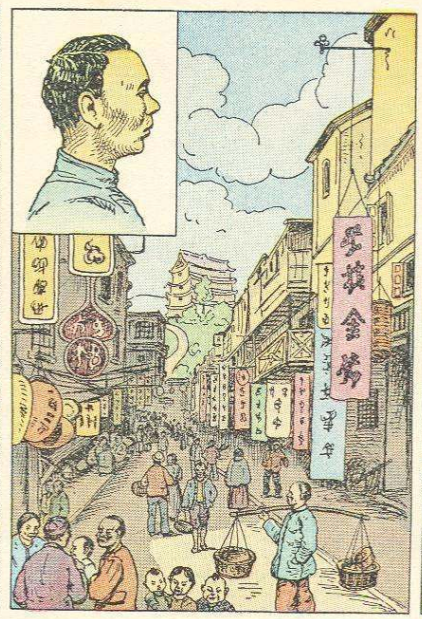

2. - Gele ras.

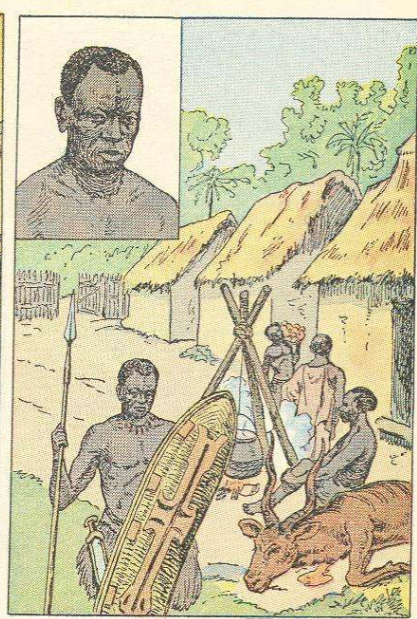

3. - Zwarte ras.

1.) The white race, which we belong to, has a white skin, usually wavy and curly hair and a strong beard. It has produced a lot of scholars, which we have to thank for their great inventions: the art of printing, telegraphy, railways, steamers, airplanes. It inhabits Europe, America, the western part of Asia and North-Africa.

2.) The yellow race includes all people with a yellow skin colour. They have a flat forehead, slit-eyes and little beard. They are very active and very patient. Their clothing and their houses differ completely from ours. The yellow race mainly inhabits Central and East Asia.

3.) The black race, or Negro race, has a black skin, thick lips, frizzy hair, but little beard. The Negros are generally less active than the other races. Because they live in warm countries, they wear few clothes. They live in huts. The black race populates Central and Southern Africa and a part of Oceania and America."

De Procure, +/- 1950, p. 41 
Figure 2. The geographical distribution of the races.

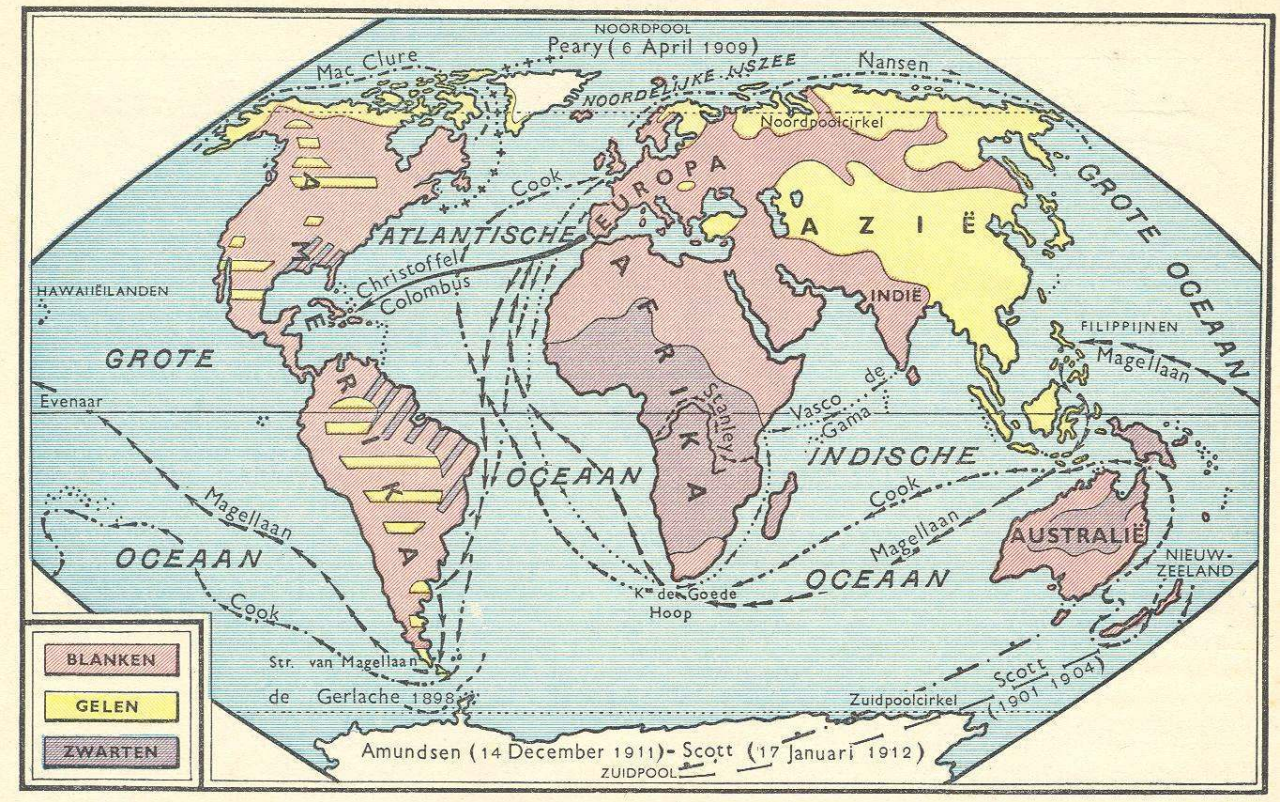

De Procure, +/- 1950, p. 41

Reading such a quote nowadays, it is striking that it does not only present a triple classification of humankind, but also an implicit ranking of the different races (cf. Depaepe, 2008). The textbook indicates, for example, that yellow people are very patient and that black people are generally less active than the other races. The accompanying illustration does not leave a lot of room for interpretation either (figure 1). While the white man is wearing a suit, the yellow man is dressed in a colorless shirt and the black one in a straw skirt. In addition, the drawing shows that white people live in orderly cities with cathedrals and grand mansions. Yellow and black people, on the other hand, have to survive in chaotic, overpopulated streets with wooden houses or in tiny clay huts in the jungle. The conclusion of the textbooks is rather predictable: the white race is the most civilized; all other races are relegated to lower rungs on the ladder of civilization:

"Nowhere on earth lives a race which equals the intelligence and the ingenuity of the white race" (Heylen, 1922, p. 231).

"Of all human races, the white race is the most civilized" (Roland, 1896, p. 279).

Obviously, such statements had a political agenda. The classification of humanity in three different races, with different physical, psychological and phenotypical characteristics, justified the European colonization of Africa. The stereotypical description of Congolese people in Flemish textbooks had to prove that the colonization of Congo was not only possible, but also desirable (Vincke, 1991, p. 65). From the quote below, it appears, indeed, that it was the moral obligation of members of the white race to introduce civilization in Africa. The quote also suggests that such a civilization process was likely to be successful: the black man "cannot invent or improve things", but "has the precious talent that he can quickly imitate what he has seen demonstrated". He is also a "born trader":

"1. The Negros are underdeveloped. They are caught in old habits. They cannot invent or improve things. For centuries, there have been skilful smiths, experienced potters and fine braiders in Congo. The population remains crazy about simple music and savage dancing, for which uncomplicated playthings like gong, tam-tam and all sorts of drums made from tree trunks are used. The Negro 
never had any exercise, nor has he linked up with more developed nations. He has not used written books. That is why he has stayed very much behind. His memory is short, except for normal things. His imagination is strong and jumps into exaggeration easily. His intellect declines fast with the years.

2. The Negro is a born trader, gifted with the best exchanging and selling skills. He likes to travel to far-away public markets to sell something or to buy the essential clothing items.

3. In addition, he has the precious talent that he can quickly imitate what he has seen demonstrated. He learns all sorts of crafts easily and becomes gradually amenable to higher civilization" (Heylen \& Sieben, 1939).

\section{The racial classifications of the post-colonial era}

11 Once most African countries had been decolonized, it was less essential to invoke the superiority of the white race to justify the colonial project. After the holocaust, terms like the Jewish race or the Nordic variety also became simply unacceptable. Nowadays, there is not a single textbook which still maintains that black people are the least civilized and that they are lazy. Instead of writing about the "simple music" and the "uncomplicated playthings like gong, tam-tam and all sorts of drums" (cf. supra), textbooks now elaborate on the "originality of the instrumentation" of African musicians (Geogenie 3 \& 4 ASO, 2002, p. 33). The fascination for the bodily markers of race seems to have disappeared as well. The attention that a textbook in 1982 called to the skin colour, hair, nose, lips and skull shape of a group of photographed Bantu children is a scandalous relict from a shameful past (figure 3). 
Figure 3. "The Bantu children looking at you from figure 3 with mixed feelings, have some characteristics in common: the skin colour? The hair? The nose? The lips? The skull shape?"

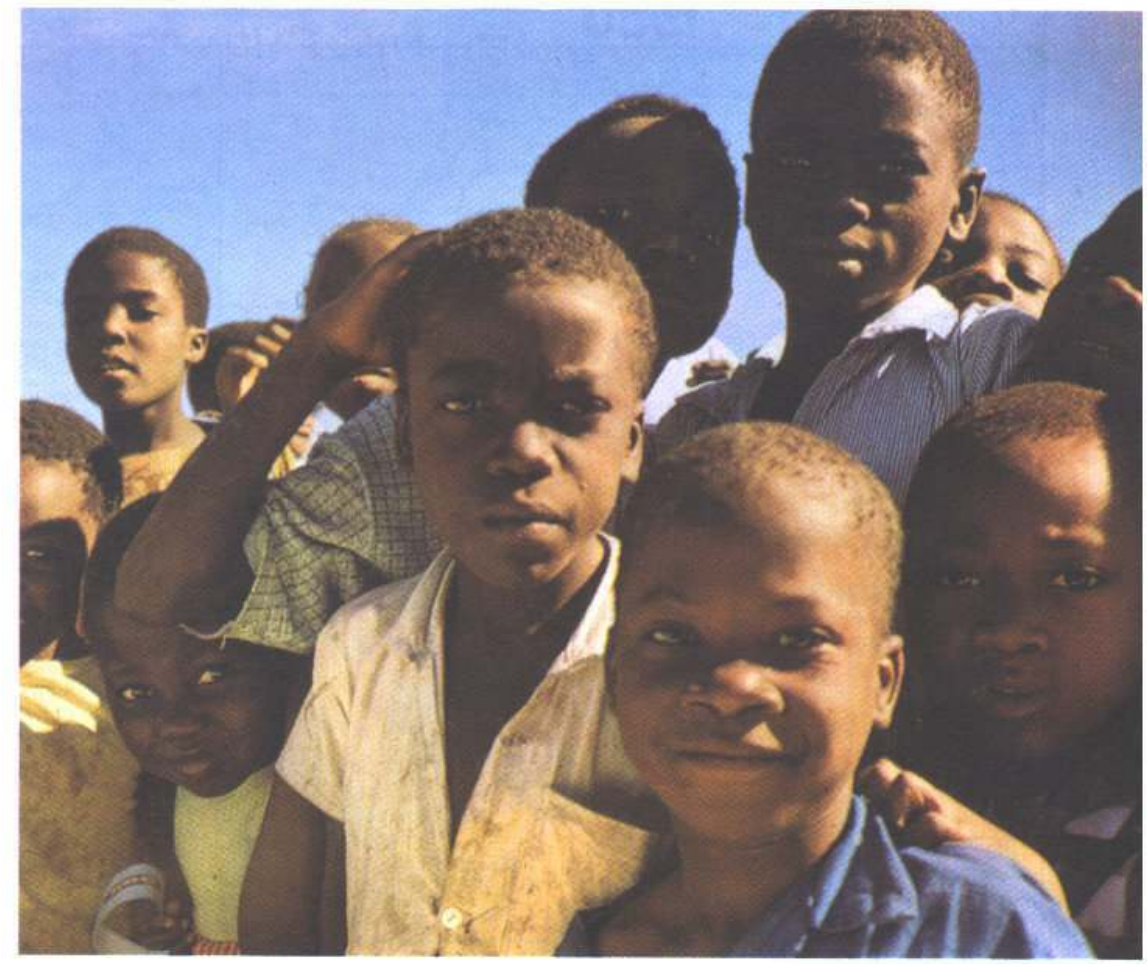

DE BANTOE KINDEREN diE JE VANOP FIg. 3 MET gEMENgDE gEVOELENS AANKIJKEN, HEBEN EEN AANTAL KENMERKEN gEMEEN : DE HUIDSKLEUR, HET HAAR, DE NEUS, DE LIPPEN, DE SCHEDELVORM?

DEBULPAEP, DE ROECK \& TILMONT, 1982, P. 17

The racial doctrine has not disappeared completely from the textbooks, however. The teaching material keeps referring to the white race, the yellow race, the black race and different mixed races. Racial characteristics still play an important part in the description of Latin America and the United States, for instance. In the United States, the textbooks rely on a simplified version of the categories from the official government statistics (figures 4 and 5). In Latin-America, the classification is characterized by a division in three races and three mixed races (see figures 4 and 5):

"The European colonists intermingled with the Indians and the imported Negro slaves so that Latin America is characterized by a large group of mixed races: Mestizos (European x Indian), Mulattos (European x African), Zambos (Indian x African)" (Werelddelen 4, 1997, p. 120). 
Figure 4. Composition of the population of the USA in ethnic groups or races.

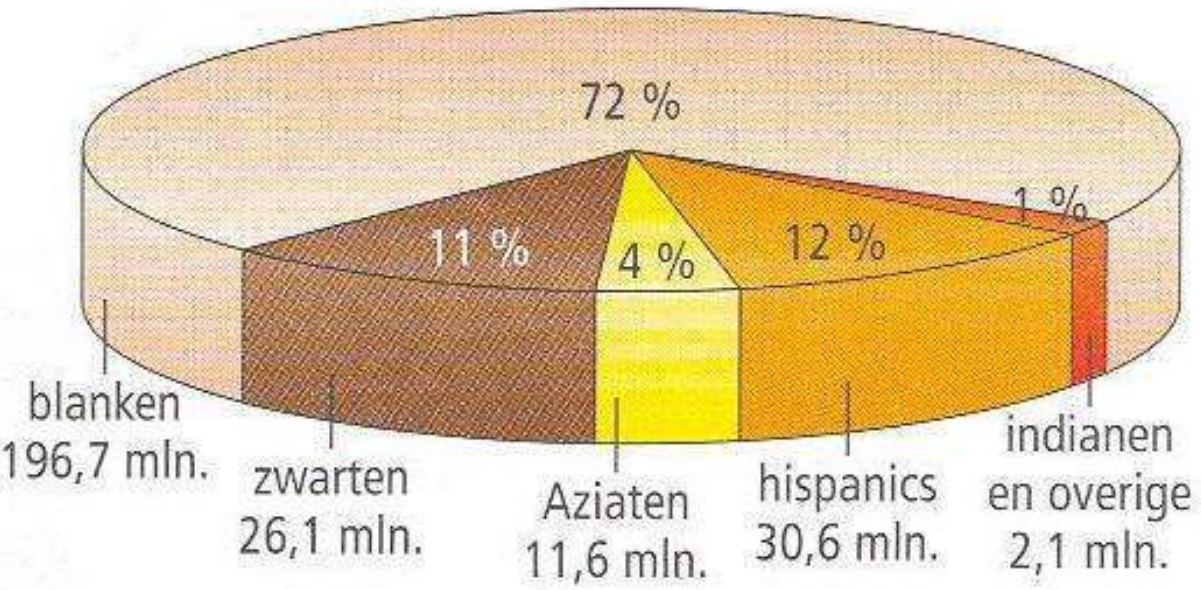

Wereldvisie 4 ASO, 2002, p. 108

Figure 5. Composition of the population of the USA in ethnic groups or races.

\begin{tabular}{|l|r|r|}
\hline (1988) & \multicolumn{1}{|c|}{ absoluut } & aandeel \\
\hline Hispánicos & $24,2 \mathrm{mln}$. & $9,5 \%$ \\
Andere blanken & $190,8 \mathrm{mln}$. & $74,8 \%$ \\
Zwarten & $30,3 \mathrm{mln}$. & $11,9 \%$ \\
Indianen en eskimo's & $1,9 \mathrm{mln}$. & $0,7 \%$ \\
Aziaten en Polynesiërs & $7,9 \mathrm{mln}$. & $3,1 \%$ \\
\hline TOTAAL & $255,1 \mathrm{mln}$. & $100,0 \%$ \\
\hline
\end{tabular}

Werelddelen 4, 1997, p. 75 
Figure 6. "Mullatos, mestizos and zambos: cross-breeds".

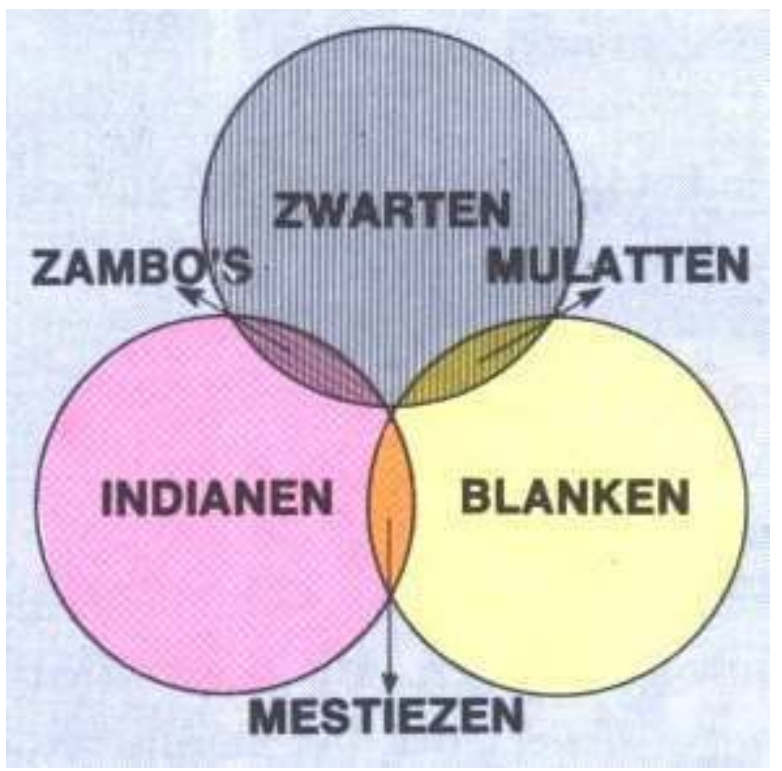

Melkebeke \& De Meyer, 1978, p. 36

Figure 7. "The distribution of races and languages in Latin-America".

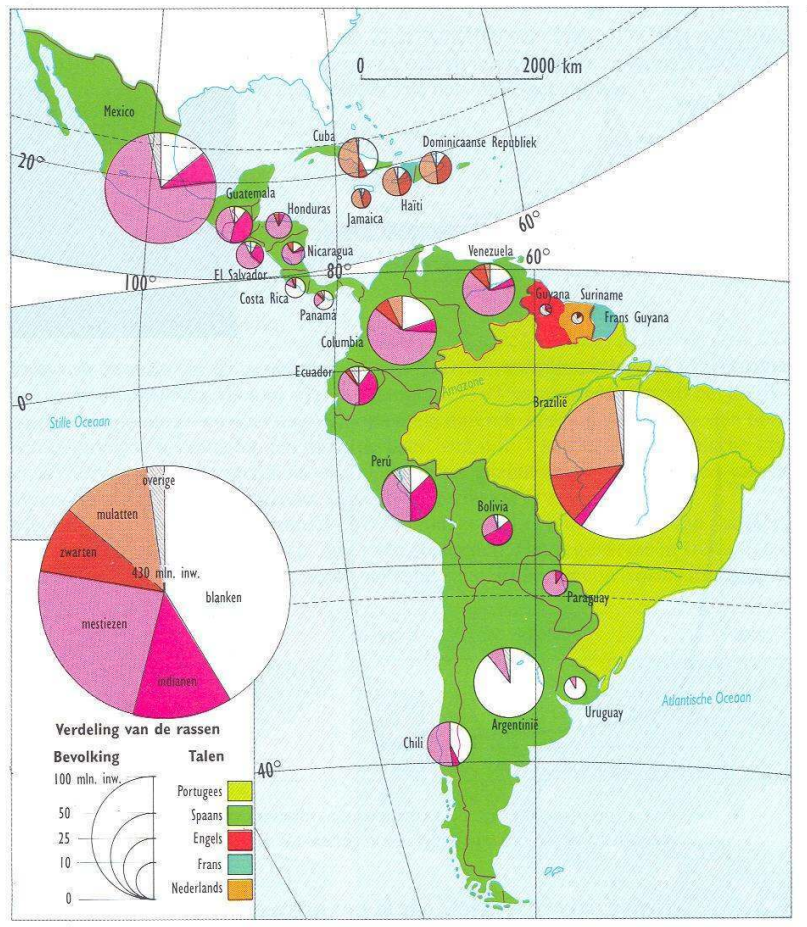

Werelddelen 4, 1997, p. 121

Thoughtful students should notice two things. First of all, it is strange that the immigrated whites, blacks and Indians from Latin-America cannot be added to the whites, blacks and Indians living in the United States already. Whether they are white, black or Indian according to the Latin-American classification actually does not seem to matter. 
Once they have crossed the Rio Grande, they are Hispanics. Secondly, it is remarkable that these Hispanics are considered to be whites: "The Hispanics are the Spanish-speaking immigrants from Latin-America. They are mainly whites" (Wereldvisie 4 ASO, 2002, p. 108). Yet, according to figure 7 only a fraction of the Latin American population is white. Somehow, the Latin-Americans seem to be white-washed at the border.

Working through this example, it becomes clear that the classifications used in the textbooks are not immutable representations of a given reality, but the product of human thought (Jackson \& Penrose, 1993). Whether you are considered to be white, black, Indian or Hispanic, is a social construct, not the result of your genetic characteristics. As a product of human thinking, race is part and parcel of a long history (and present) of discrimination. According to a thirty-five year old exemplar (!), the conclusion that race is not something natural is obvious (see figure 8):

"Biochemical research strongly relativizes the meaning of anthropometric classifications and the importance that can be attached to them from a scientific perspective" (Debulpaep et al., 1977, p. 25).

Figure 8. "Average number of different nucleotide pairs in the DNA as a consequence of mutations: a.) between parents and their children; $b$.) between two random people of the same sub-race; $c$.) between two random people of two different sub-races".

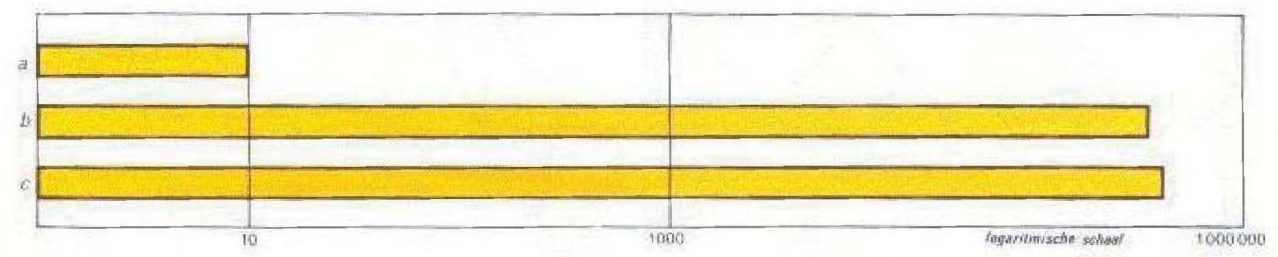

\section{The cultural classifications of the post-colonial era}

\section{"Our" culture and "the other" culture}

After the Second world war, the focus of the geography textbooks slowly shifted from supposed racial differences to cultural traits. For many manuals, the arrival of "guest workers" from Italy, Greece, Morocco and Turkey did not create a multiracial society, but a multicultural one (according to the racial classifications, all these immigrants were whites anyway). Yet, this multiculturalism was silenced in geography lessons for a very long time. Even in the 1980s, textbooks were published without any reference to immigrants (Vincke, 1985, p. 105). From the 1990s onwards, this started to change, however:

"Recently, we can find cultural elements in our urban landscapes which are a bit strange to us: inscriptions which we do not understand and buildings whose function we do not know well. In some neighborhoods, we encounter people with their own neighborhood life. We can tell this from the people themselves (costumes, language, social life, religion) and from the shops and services (groceries, bakeries, butcheries and cafés)" (Geogenie 1 \& 2, 1999, p. 73).

"In the streets of mainly urban municipalities, the migrants from Morocco and Turkey catch our eyes. In some city quarters of our big cities these migrants catch our eyes because of their different culture, which rests on Islam, as revealed sometimes in a different costume and different customs than we have. Their 
different culture can count on the respect of the Flemish youth" (Wereldvisie 1, 1998, p. 65).

In both quotes, the shameless fascination for the bodily otherness of other races is replaced by a blatant focus on cultural characteristics which are connected to the body as well. The two textbooks point to "different" customs and "different" costumes (figure 9). They also use words like "strange" and "catch our eyes". This bodily otherness, the students learn, is part of a larger dichotomy between "our culture" and "their different culture". As such, both quotes present a polarized representation of cultural relations in which "they" and "them" are the direct opposites of "we" and "us" and in which "different customs" cannot be identified with "ours" (cf. Mok, 1999, p. 348).

Figure 9. "Ethnic neighbourhood in the north east of Paris".

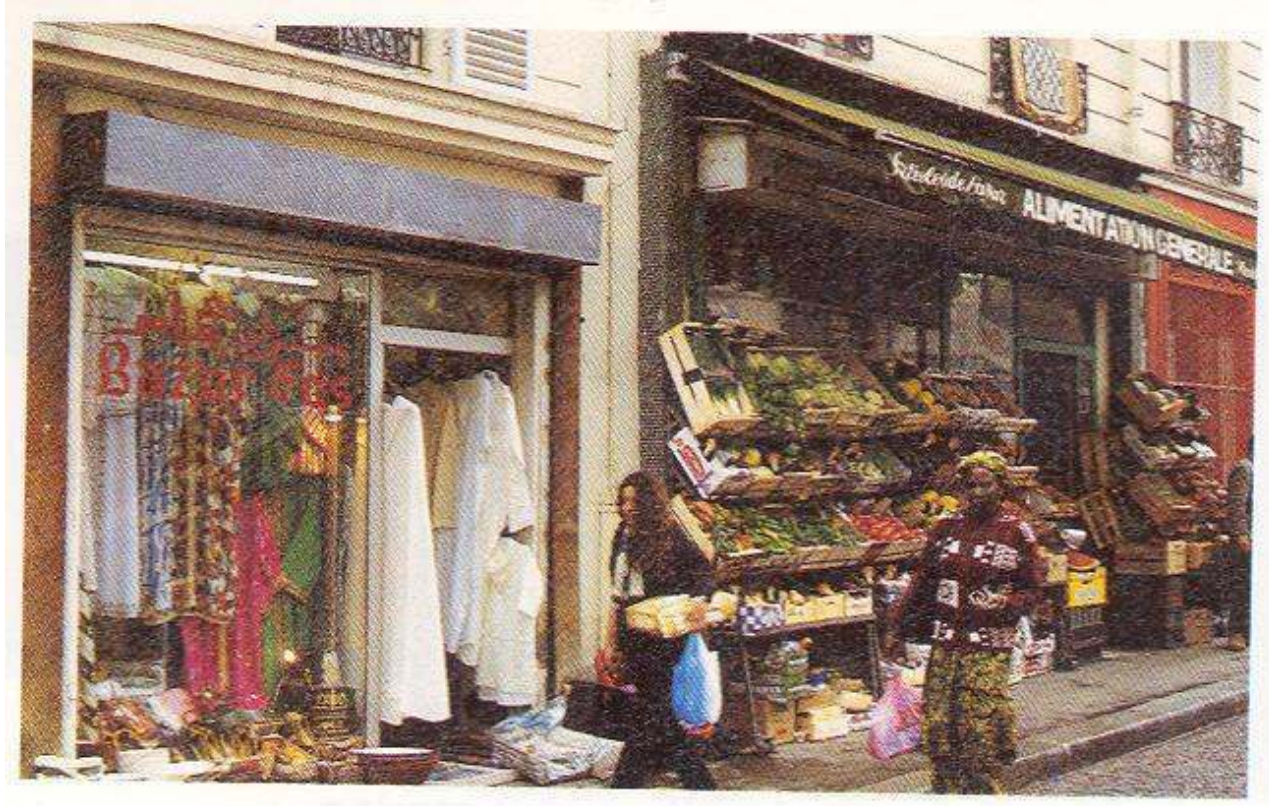

Wereldvisie 2, 1998, p. 49

This polarisation between "us" and "them" is deepened by the spatial demarcation of cultural regions. Such a cultural region is defined as a "part of a continent in which the way of life, the development and the culture are more or less the same" (GEO 3 ASO, 2001, p. 6). Based on this definition, the textbooks mark out about eight cultural regions: Anglo-Saxon America, Latin America, Europe, the Islamic World, Black Africa, Russia, South-East Asia and Oceania (figure 10). That explains why Turks and Moroccans are said to "catch our eye because of their different culture", while the migrants from Italy, Spain or Greece do not: Morocco and (most of) Turkey are part of another cultural region, while Italy, Spain and Greece are not. 
Figure 10. GEO 3 ASO, 2001, p. 6.

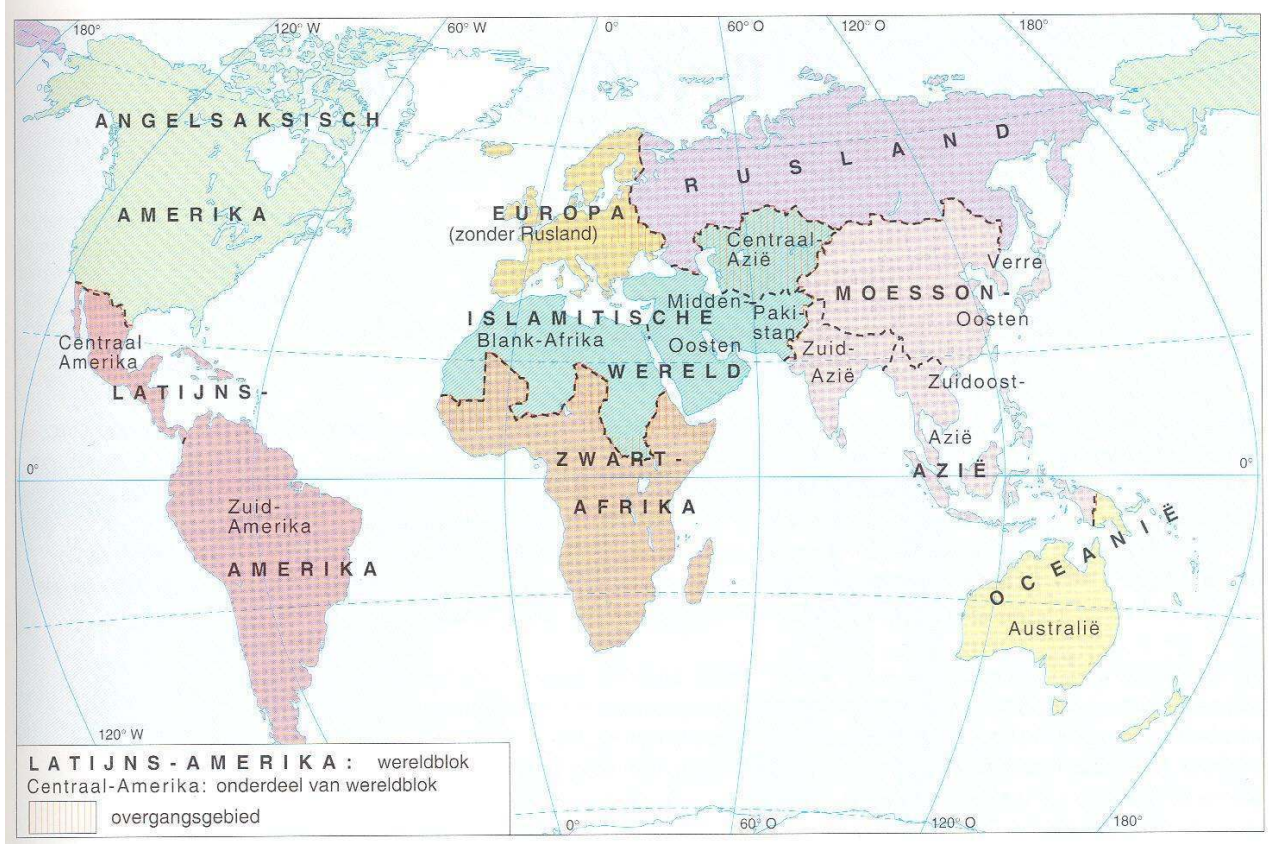

\section{"Migrant neighbourhoods" and "neighbourhoods of autochthons"}

A second spatial aspect of the same dichotomy can be found at the scale of the city. According to the textbooks, multiculturalism is only an urban phenomenon. It is discussed under headings such as "Brussels, multicultural capital" (Wereldvisie 2, 1998, p. 44) or "ethnic and social differences in large cities" (GEO 2, 1998, p. 44). The two quotes in the beginning of this section place the "cultural elements" "which are a bit strange to us" also "in the streets of mainly urban municipalities" (Wereldvisie 1, 1998, p. 65) and "in our urban landscapes" (Geogenie 1 \& 2, 1999, p. 73). Within the cities, the textbooks discuss an "ethnic neighbourhood" (figure 9), a "guest workers' neighbourhood in Brussels" (figure 11), "living neighbourhoods for migrants" (figure 12) and "working class neighbourhoods of autochthons" (Geogenie 1 \& 2, 1999, p. 85). 
Figure 11. "Guest workers' neighbourhood in Brussels".

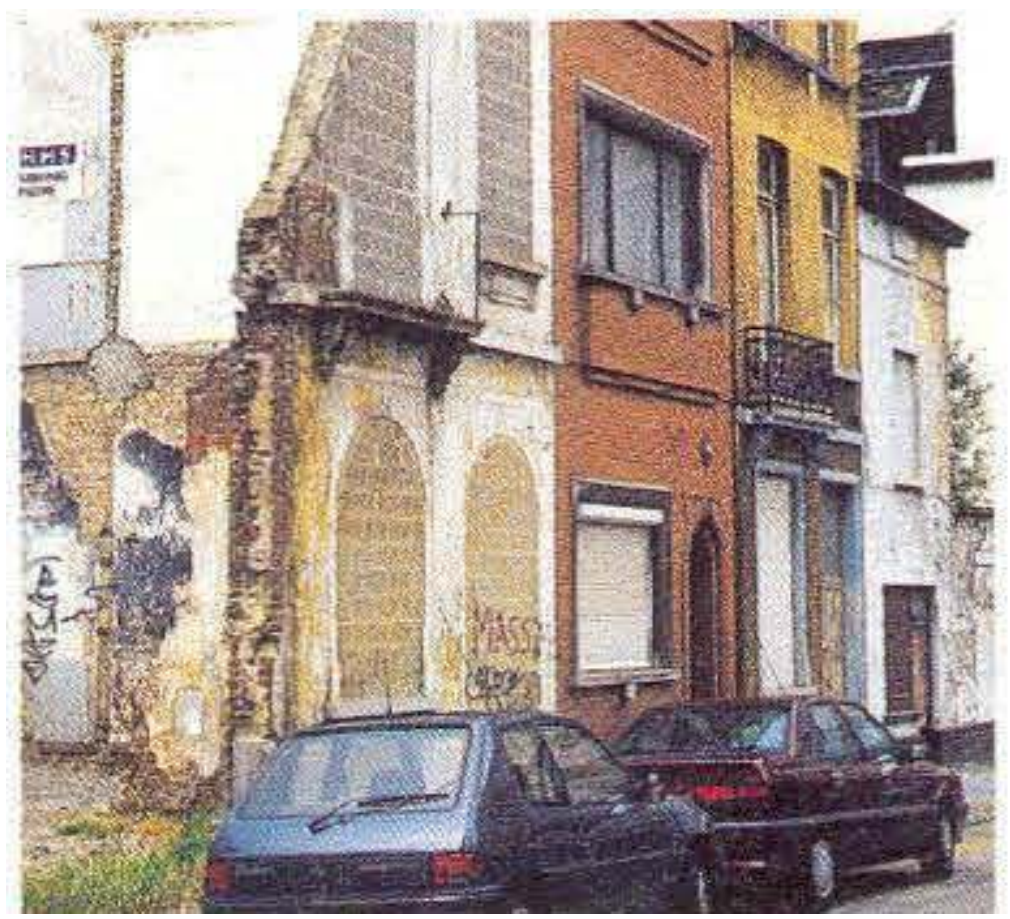

Wereldvisie 2, 1998, p. 52

Figure 12. "Living neighbourhoods for migrants".

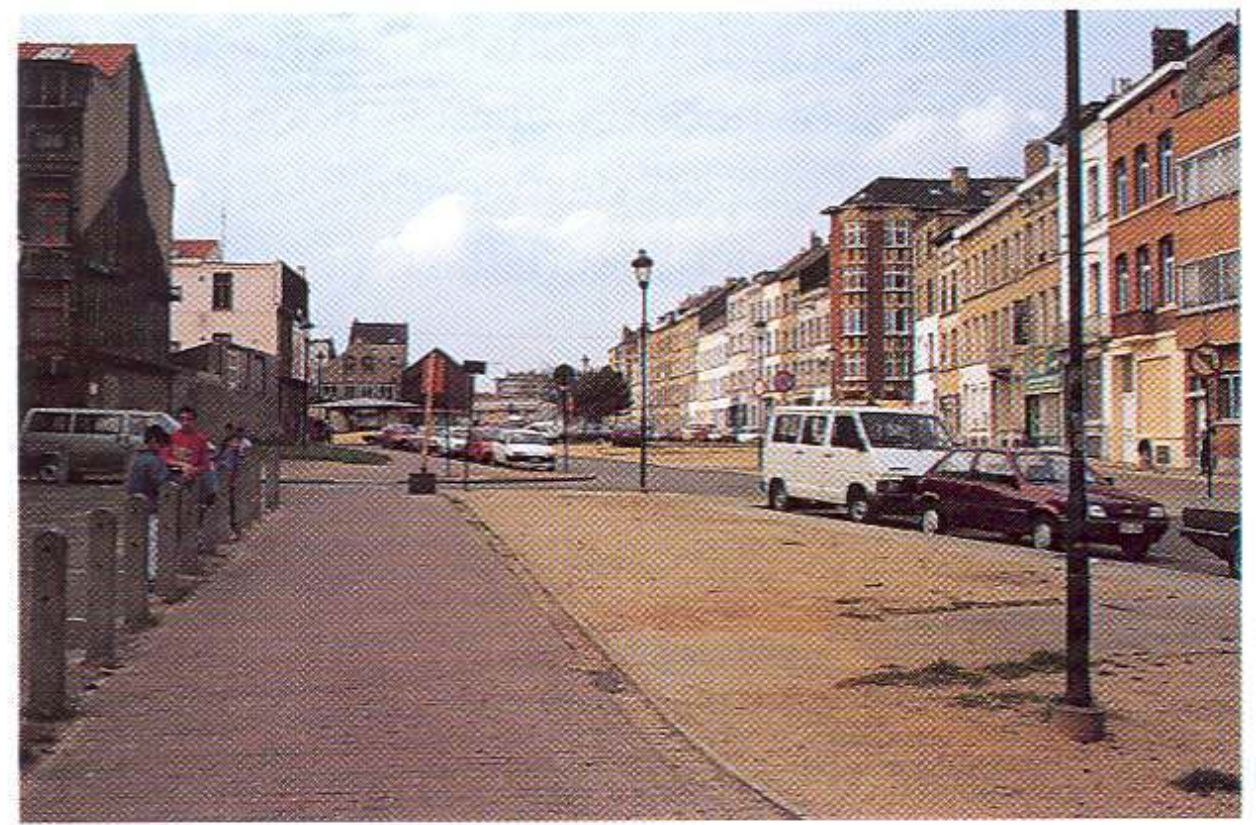

Geogenie 1 \& 2, 1999, p. 84

19 This approach is problematic because it confines multiculturalism to a limited number of urban neighbourhoods. In the textbooks, Brussels and Antwerp are depicted as 
multicultural cities. The rest of the country (and Europe at large, see figure 10) are represented as cultural monoliths. Such a simplified dichotomy between the white countryside and "neighbourhoods of autochthons", on the one hand, and multicultural cities and "neighbourhoods for migrants", on the other hand, is simply incorrect. Despite the high levels of segregation, there are no neighbourhoods in Belgium where only autochthons or allochthons live (Kesteloot, 2006). Maintaining such an illusion also prevents students from rural and suburban municipalities from seeing their responsibility in bringing about a tolerant, multicultural society.

\section{From Yugoslavia to Borgerhout: the clash of cultures} to generate conflicts. Referring to Yugoslavia, "where people with a different language, culture and religion live together in one country", a textbook concludes that "if communities with a different language or culture are living in the same country, this can cause conflicts" (GEO 2,1998 , p. 44). Following the logic of Samuel Huntington's clash of civilizations (1996), the textbook predicts conflicts in multicultural cities such as Brussels as well, but finds it crucial to distinguish between two groups of people:

"On the one hand, the immigrants from our neighbouring countries. Because of their language, prosperity and way of life they differ little from most autochthons and they do not catch the eye. On the other hand, Moroccans and Turks, joined by some immigrants from Eastern- and Southern-Europe. Because of their different way of life, language and culture, they come into conflict situations with the Belgians sometimes" (GEO 2, 1998, p. 44).

Other textbooks agree that it is difficult to live together with different cultures. "Under which circumstances can young people come into conflict with other neighbourhood dwellers?" The answer: "Especially in places where cultural differences go hand in hand with less wealth, can tensions between allochthons and authochthons arise" (Geogenie 1 \& 2, 1999, p. 85-87).

Some textbooks go even further. They underline that tensions and conflicts do not have their roots in cultural differences or socio-economic circumstances, but in the presence of foreigners themselves:

"In Brussels there are serious problems because of the large number of foreigners (...). The concentration of Moroccans in Borgerhout brings about tensions with the autochthonous population in Antwerp too" (Algemene Aardrijkskunde 5, 1994, p. 119).

Another textbook cites the news magazine Knack, but comes to the same conclusion:

[During a shoot-out and subsequent protests of young immigrants], "the underlying problems of the neighbourhood reappeared again. More than 60 per cent of the residents are immigrants. As much as 38 nationalities can be counted, among them numerous African refugees" (Wereldvisie 2, 1998, p. 52).

\section{Raising awareness of discrimination}

Flemish geography textbooks rarely write about racism and ethnocentrism. While they attribute conflicts between autochthons and allochthons to the large numbers of foreigners in cities, the concentrations of Moroccans and Turks in certain neighbourhoods, "their" different cultures, "their" different languages and "their" 
different ways of life, they rarely blame "our" intolerance, "our" xenophobia or "our" racism. Instead, they claim that "their different culture can count on the respect of the Flemish youth" (Wereldvisie 1, 1998, p. 65).

Discussion about the high levels of ethnic and racial segregation illustrate this. The textbooks give different explanations why (the children and the grandchildren of) immigrants are concentrated in the poorest neighbourhoods of Belgian cities:

"The guest workers from Turkey and the Maghreb countries ended up in the central districts and along the former industrial axis characterized by its dated houses" (Wereldvisie 2, 1998, p. 52).

"The comfort they offer does not attract the Belgian population so that these houses are consistently taken up by foreigners, guest workers in particular" (Wereldvisie 5-6 ASO, 2004, p. 27).

"The unoccupied and old houses attract foreigners and poor people" (figure 13; Wereldvisie 5-6 ASO, 2004, p. 28).

\section{Figure 13. "Decay and poverty in poor neighbourhoods".}

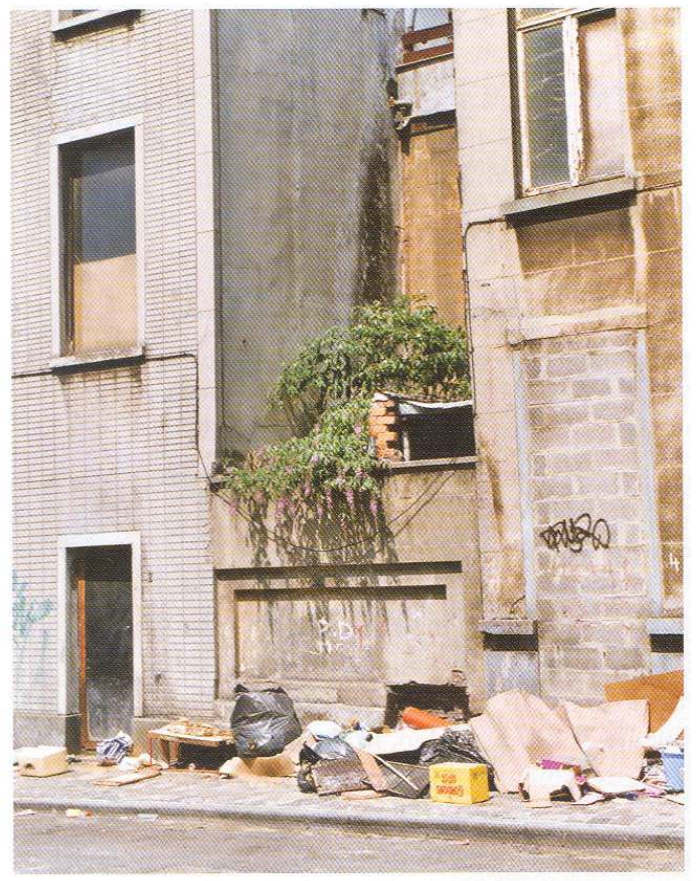

Verbs like "end up", "take up" and "attract" disguise the inconvenient truth. Generally, these people do not opt for those neighbourhoods with the worst living conditions. In most cases, their social position forces them to move into the cheapest, most disadvantaged neighbourhoods. Only one textbook discusses the housing problems from this perspective. It writes that "the socio-economic status in particular (...) determines the place population groups can or have to occupy" (Algemene Aardrijkskunde 6, 2003, p. 119). [Because of the revitalisation of the city centre], "quite a lot of poor families are forced to move to the poorest neighbourhoods in the city" (Algemene Aardrijkskunde 6, 2003, p. 120). Obviously, it is also important that many landlords refuse to rent their houses to 
foreigners. In the textbooks, discrimination on the housing market is only discussed with regards to the situation in the United States, however:

"Because of the arrival of ethnic minorities in Harlem, the white inhabitants did not want to live in the north-eastern part of Manhattan anymore and they moved. The minority groups, for their part, are not welcome in other neighbourhoods. People, for example, refuse to rent their houses in other neighbourhoods" (Werelddelen 4, 1997, p. 117).

\section{Discussion: four critiques}

27 So far, this paper has focused on the depiction of other races and cultures in Flemish geography textbooks. The conclusion is that most textbooks published in the (recent) past imposed an ethnocentric and racist world view upon students. Before the decolonization of Africa, the division of humanity in different races was a self-evident component of all textbooks. A triple classification of humankind was complemented with a psychological profile of the three different races. This psychological profile was explicitly associated with a hierarchical ranking of the different races that justified the colonial project.

Even though references to race have never disappeared completely, such anthropometric classifications have largely been replaced by a focus on cultural elements like language, clothing and religion. In this process, a biological understanding of race has been supplemented by a social and cultural framing of race (cf. Blaut 1992). While this shift has to be applauded at first sight, closer inspection reveals that the cultural classifications are as problematic as the racial ones. Giving testimony to the fact that racism changes its colours with social, economic and political evolutions, the racism adopted by the textbooks has evolved from a biological racism centred around the belief that some races are superior to others to a cultural racism in which humans are considered to be more equal, but where different cultures are considered to be so hostile that cultural differences make it natural for national states - or smaller spatial entities - to form closed communities (cf. Wren, 2001, p. 143).

Throughout the different textbooks, this is evident in four different, but related issues. First of all, it is clear that the differences between cultures are exaggerated, while the internal differences are ignored. According to the textbooks, immigration from the "Islamic World" to "Europe" has generated a bicultural society in which "our" culture is completely different from "their" culture, in which their "different customs" cannot be identified with "ours" and in which "neighbourhoods of autochthons" border "migrant neighbourhoods". In this caricatural view, Turks and Moroccans are lumped together, while the distinction between Berbers and Arabs is never mentioned. The cultural world map does not leave any room for the millions of Jews in Israel, Copts in Egypt or Christians in Sudan. Neither is there any attention for the millions of Muslims in Indonesia, Bangladesh or India. To understand many of the fault lines that run through the world today, the straightforward division of the world in cultural regions is overly simplistic and ultimately wrong.

30 A second problem is that the definition of culture is too static. Just like the racial classifications wrongly suggest that it is possible to classify humanity in a limited number of pure and unchanging races, the division of the world in cultural regions implies that there is a small amount of isolated and independent cultures. Such a view does not leave 
any room for endogenous variations or exogenous changes, however. For the textbooks, everybody is born in one culture and dies in the same culture. Yet, to understand the hybrid world we are living in, it is essential that cultures are the result of contact and exchange with other cultures. In practice, it is hard to imagine, for example, that Muslims living in Belgium are not influenced by the Flemish, Belgian or European culture, and vice versa.

31 Thirdly, it is problematic that conflicts are attributed to "their" concentration, "their" different culture and "their" different way of life. While it should not be denied that living together in a multicultural society is not always easy, more attention is needed for "our" discrimination, "our" xenophobia and "our" ethnocentrism. Rather than scapegoating immigrants, it should be stressed that all inhabitants of superdiverse neighborhoods, countries or continents are challenged to accommodate each other.

Finally, it is a major issue that the textbooks do not address all students. While the old textbooks wrote about he "the white race, which we belong to", the new ones refer to " cultural elements (...) which are a bit strange to us": inscriptions which we do not understand and buildings whose function we do not know well". Yet, for many students, some of these " different customs" might not be that "strange" at all. By saying that particular buildings, shops and inscriptions are "strange" and "different" from "ours", the textbooks stigmatize people with an immigrant background. In order to involve everyone in the classes, it is necessary to drop the exclusionary us-and-them-perspective (cf. Mok, 1995, p. 28).

\section{Conclusion: four propositions}

Drawing on these four critiques, I would like to conclude with four propositions. First of all, it is clear that twenty-first century textbooks should not propagate racial divisions anymore. The terminology stems from an era when social scientists were limited to the determination of the skin colour and the measurement of the skull shape. As such, the present use of these anthropometric classifications entails the acceptance and reproduction of racist ideas of nineteenth century anthropologists. As has been indicated already by the 1977 textbook cited at the end of section 2.3, it is clear that the genetic variability between people cannot be reduced to a limited number of races, sub-races and mixed races (Reardon, 2004). School geography should remove all references to the biological meaning of race and replace it with a refutation of the racial classifications based on the progress made in genetics and biochemistry (cf. Vincke, 1991, p. 70).

Secondly, geography textbooks should encourage students to realize that many apparently opposite terms, like black and white or autochthon and allochthon, are less dichotomous than they appear at first sight. Students need to be confronted with a complex and nuanced conceptualization of social differences that leaves room for dynamics, variations and contradictions. This means that we need to get rid of overly simplistic classifications of human diversity which are limited to the fault lines of race or culture. Instead, we should adopt a more subtle, non-essentialist view of the world that has respect for the singularity of individuals and their unique position within a "matrix of domination" (Collins, 1990) that involves race, class, culture, gender, sexuality and many other dimensions as interlocking forms of oppression.

Thirdly, it is essential to adopt a social constructivist approach. In the words of Jackson and Penrose (1993, p. 3) "many of the categories that we have come to consider 'natural' 
and hence immutable, can be more accurately (and more usefully) viewed as the product of processes which are embedded in human actions and choices". For this reason, we should stimulate students to understand that terms like "white", "European" or "Islamic", which seem neutral and natural at first sight, do not have the same meaning everywhere and carry a history of inclusion and exclusion. One way to accomplish this would be to focus on the social construction of the categories used in the textbooks. The example of the Mexican who becomes white-washed at the border with the United States is a case in point (see section 2.3). The history of the social construction of Europe would be another one.

Fourthly, it is crucial that teachers discuss themes such as xenophobia, racism and discrimination with their students (cf. Carignan et al., 2005, p. 391). Currently, textbooks do not only talk the students into a negative image of cities, but also into an implicit approval of their discriminatory practices. As long as students are not confronted with the pernicious consequences of their own stereotypes and prejudices, the social status quo will not be challenged. Rather than projecting discrimination on the residents of the United States, as the citation at the very end of section 4 does, we should recognize that racial privileges, prejudices and injustices have all but disappeared from our society.

Geography textbooks can never be neutral (cf. Kesteloot and Saey, 1981; Peleman, 1998; Van Dijk, 2005). Just like the description of the Congolese in old geography textbooks could easily degenerate into racist clichés justifying the colonization of Africa, the generalizations offered today slip too easily into racist platitudes and ethnocentric stereotypes. Even though students and teachers can read textbooks in manifold ways, there is a serious risk that the strong focus on cultural otherness, the one-sided explanation of cultural conflicts and the manifest silence on discrimination and xenophobia that is present in the more recent geography textbooks (re)produces xenophobic attitudes and racialized prejudices. If we aim to motivate all students to become part of a more inclusive and more just society, we should, therefore, seriously rethink the way we present the world they are living in.

\section{BIBLIOGRAPHY}

\section{Academic publications}

BLAUT J. (1992), “The theory of cultural racism”, Antipode 24, 4, pp. 289-299.

CARIGNAN N. POURDAVOOD R.G. KING L.C. FEZA N. (2005), "Social representations of diversity: multi/intercultural education in a South African urban school", Intercultural Education, 16, 4, pp. 381-393.

CLAES E. DEJAEGHERE Y. FIERS S. HOOGHE M. QUINTELIER E. (2006), “Jeugdonderzoek 2006 : Een eerste portret van de opvattingen van de zestienjarige respondenten", Centre for Citizenship and Democracy, Leuven, http://statbel.fgov.be/studies/ac631_nl.pdf, 28pp.

COLLINS P. H. (1990), Black feminist thought: Knowledge, consciousness, and the politics of empowerment , London, Harper Collins. 
DEPAEPE M. (2009), "Belgian images of the psycho-pedagogical potential of the Congolese during the colonial era, 1908-1960", Paedagogica Historica: International Journal of the History of Education, 45 , 6, pp. 707-725.

HEMMING P.J. (2011), "Meaningful encounters? Religion and social cohesion in the English primary school”, Social \& Cultural Geography, 12, 1, pp. 63-81.

HUNTINGTON S.P. (1996), The Clash of Civilizations and the Remaking of World Order, New York, Simon \& Schuster.

JACKSON P. \& PENROSE J. (eds.) (1993), Constructions of race, place and nation, Minneapolis, University of Minnesota Press.

KESTELOOT C. (2006), "De geografische spreiding van de buitenlandse immigratie : grondslagen, dynamiek en maatschappelijke gevolgen”, in KHADER B., MARTINIELLO M., REA A., TIMMERMAN C. (eds.), Immigratie en integratie anders bekeken, Brussel, Bruylant.

KESTELOOT C. \& SAEY P. (1981), “De geografie is geen neutrale wetenschap. Of de maatschappelijke rol van de geografie in onderwijs en onderzoek", De Aardrijkskunde, 5, 4, pp. 439-457.

MOK I. (1995), “In aardrijkskundeboeken zijn Nederlanders nog steeds blank. Twaalf aandachtspunten voor interculturele methoden", Geografie-Educatief, 1, pp. 28-31.

MOK I. (1999), In de ban van het ras. Aardrijkskunde tussen wetenschap en samenleving 1876-1992, Amsterdam, ASCA Press.

NATTER W. \& JONES J.P. (1997), “Identity, space and other uncertainties”, in BENKO G. \& STROHMAYER U. (eds.), Space and social theory: Interpreting modernity and postmodernity, Oxford, Blackwell.

PELEMAN K. (1998), “Is er plaats voor de feministische geografie in het onderwijs ?", De Aardrijkskunde, 22, 4, pp. 37-46.

REARDON J. (2004), "Decoding race and human difference in a genomic age”, Differences, 15, 3 , pp. 38-65.

SCHUERMANS N. (2007a), "Leggen handboeken aardrijkskunde een racistisch en etnocentrisch wereldbeeld op ?”, De Aardrijkskunde, 31, 1, pp. 3-18.

SCHUERMANS N. (2007b), "Handboeken aardrijkskunde en anti-stedelijkheid”, Agora, 23, 1, pp. 22-24.

SCHUERMANS N., DE MAESSCHALCK F. (2010), "Fear of crime as a political weapon: explaining the rise of extreme right politics in the Flemish countryside", Social \& Cultural Geography 11, 1, pp. 247-262.

SPRUYT B. (2008), “Ongelijkheid en segregatie in het onderwijslandschap : effecten op etnocentrisme", Tijdschrift voor sociologie, 29, 1, pp. 60-89.

VALENTINE G. (2008), "Living with difference: reflections on geographies of encounter”, Progress in Human Geography, 32, 3, pp. 323-337.

VAN DIJK T. (2005), “Discourse and racism in Spain”, Associació de Professors d'Anglés de Catalunya, 25,1, pp. 68-75.

VINCKE E. (1985), Géographes et hommes d'ailleurs. Analyse critique de manuels scolaires, Bruxelles, Centre Bruxellois de Recherche et de Documentation Pédagogique. 
VINCKE E. (1986), “L’homme exotique dans les manuels belges de géographie édités en français”, Afrika Focus, 1986/3-4, pp. 221-249.

WREN K. (2001), “Cultural racism: something rotten in the state of Denmark?”, Social \& Cultural Geography, 2, 2, pp. 141-162.

\section{Geography textbooks 1896-1985}

DEBULPAEP C., DE ROECK M., DE JAEGER R., TILMONT J. (1977), Taken-aardrijkskunde 5 Sociale geografie, Namen, Wesmael-Charlier.

DEBULPAEP C., DE ROECK M., TILMONT J. (1982), Taken-aardrijkskunde 2 De wereld waarin je leeft, Namen, Ad. Wesmael-Charlier.

DE PROCURE ( \pm 1950$)$, Atlas Leerboek Aardrijkskunde, Door kaart en beeld voor de tweede graad, Brussel \& Namen, De Procure.

HALKIN J. (1927), Leerboek van aardrijkskunde, Derde deel : Aardrijkskunde van België, Grondbeginselen van Cosmographie, Namen, Ad. Wesmael-Charlier.

HALKIN J. (1937), Leerboek van aardrijkskunde, Namen, Ad. Wesmael-Charlier.

HEYLEN L. (1922), Aardrijkskunde van Europa, Lier, Joz. Van In \& C.

HEYLEN L. (1935), Algemeene Aardrijkskunde, Lier, Joz. Van In \& $C^{\circ}$.

HEYLEN L. \& SIEBEN, A. (1939), Belgisch Congo, Lier, Joz. Van In \& Cº

MELKEBEKE W., DE MEYER L. (1978), 'n Kijk op de werelddelen 3, Antwerpen \& Amsterdam, Standaard Uitgeverij.

ROLAND J. (1896), Tweede leercursus natuurkundige en staatkundige aardrijkskunde, Namen, Ad. Wesmael-Charlier.

SCHUILING R. (1906), Onze aarde geschetst naar haar natuurlijke landschappen, II Europa, Zutphen, Thieme \& $\mathrm{C}^{\circ}$.

TROCH A. (1955), Aanvankelijke aardrijkskunde, Lier, Joz. Van In \& $\mathrm{C}^{\circ}$.

\section{Geography textbooks 1985-2009}

ALGEMENE AARDRIJKSKUNDE 5 (1994), Kapellen, Pelckmans.

ALGEMENE AARDRIJKSKUNDE 6 (2003), Kapellen, Pelckmans.

GEO 2 (1998), Deurne, Wolters Plantyn.

GEO 3 ASO (2001), Deurne, Wolters Plantyn.

GEOGENIE 1\&2 (1999), Antwerpen, Standaard Uitgeverij.

GEOGENIE 3\&4 ASO (2002), Antwerpen, De Boeck.

GEOGENIE 5\&6 ASO (2004), Antwerpen, De Boeck.

STANDAARD AARDRIJKSKUNDE 3 (1995), Antwerpen, Standaard Uitgeverij.

VISIE OP LEEFRUIMTEN IN DE SOWJETUNIE EN AMERIKA (1986), Kapellen, Pelckmans.

WERELDDELEN 4 (1997), Kapellen, Pelckmans.

WERELDVISIE 1 (1998), Kapellen, Pelckmans.

WERELDVISIE 2 (1998), Kapellen, Pelckmans.

WERELDVISIE 4 ASO (2002), Kapellen, Pelckmans. 
WERELDVISIE 5-6 ASO (2004), Kapellen, Pelckmans.

\section{ABSTRACTS}

The final attainment levels of Flemish secondary geography education stress the importance of respect for other societies and the specific way of life of other people. As a consequence, curricula focus more than ever on topics such as the global north-south divide, migrations and the multicultural city. Drawing on an analysis of fifty Flemish geography textbooks published between 1896 and 2004, this paper critically addresses the way in which these topics have been presented. The study reveals that an emphasis on racial differences has been largely replaced by a focus on cultural differences. Yet, because of the strong emphasis on cultural otherness, the one-sided explanation of cultural conflicts, the manifest silencing of discrimination and xenophobia and the use of an exclusionary us-them-perspective, the textbooks (re)produce a racist and ethnocentric world view among young people in Flanders. Hence, the article concludes with four propositions for geography textbooks which motivate students to become part of a more inclusive, more diverse and more just society.

In Vlaanderen hebben de eindtermen van het vak aardrijkskunde in het secundaire onderwijs het belang van respect voor andere leefwijzen en culturen opgenomen. De leerplannen focussen dan ook meer dan ooit op onderwerpen zoals de noord-zuid kloof, migratie en de multiculturele stad. Op basis van een analyse van 50 handboeken aardrijkskunde die gepubliceerd zijn tussen 1896 en 2004 bekijkt dit artikel de voorstelling van deze onderwerpen op een kritische manier. Op die manier wordt duidelijk dat een nadruk op raciale verschillen grotendeels plaats gemaakt heeft voor een focus op culturele verschillen. De sterke nadruk op culturele andersheid, de eenzijdige verklaring van culturele conflicten, het manifeste toedekken van discriminatie en xenofobie en de hantering van een uitsluitend wij-zij-discours zorgen er echter voor dat de handboeken een racistisch en etnocentrisch wereldbeeld verspreiden. Zodoende besluit het artikel met vier voorstellen voor handboeken die leerlingen motiveren om deel te worden van een meer inclusieve, diverse en rechtvaardige maatschappij.

INDEX

Keywords: geography textbooks, diversity, racism, ethnocentrism, Flanders

Trefwoorden handboeken aardrijkskunde, diversiteit, racisme, etnocentrisme, Vlaanderen

\section{AUTHOR}

\section{NICK SCHUERMANS}

Department of Earth and Environmental Sciences, KULeuven, Centre on Inequalities, Poverty, Social Exclusion and the City, University of Antwerp, Nick.Schuermans@ees.kuleuven.be 